\title{
How Important is Vocational Public Relations Support in Establishing Partnerships with the Business World/Industrial World (DU/DI)?
}

\author{
Yuli Agustina1; Rosalina Dhea Anisa Chintya Dewi², Andi Basuki ${ }^{3}$ \\ State University of Malang \\ E-mail: yuli.agustina.fe@um.ac.id
}

\begin{abstract}
This study aimed to determine the public relations activities of vocational high schools (SMK) in connecting between schools and the community, one of which is DU/DI. The purpose of this study was to determine public relations activities at SMK, forms of partnership with DU/DI and forms of public relations activities in supporting partnerships with DU / DI at SMK. This type of research was qualitative research. Collecting data was from a natural setting by using the researcher as a key instrument. Sources of data in the study were the results of interviews, documents, and social environment. The form of vocational partnership with DU/DI consisted of 9 cooperation forms and forms of public relations activities in support of partnerships with DU/DI was to conduct industry visits regularly, renewed the form of cooperation with DU/DI, as well as being an intermediary between Internship students and DU/DI. Overall results illustrated that school public relations activities in collaboration with DU/DI had been going well, but it had not been maximized.
\end{abstract}

Keywords: Public Relations, Partnerships, and DU/DI

\section{INTRODUCTION}

The implementation of vocational education was intended to prepare students to have skills so they could fulfill needs of the middle-level workforce. This education has a mission to help students compete in employment and careers in the workforce. Vocational education is part of the national education system that aims to prepare workers who have the skills and knowledge under the requirements of employment and can develop their potential in adopting and adapting to technological developments (HR Division, 2014).

Vocational High School (SMK) in Government Regulation of the Republic of Indonesia Number 66 of 2010 concerning Amendment to Government Regulation Number 17 of 2010 concerning Management and Implementation of Education is "one form of formal education unit that organizes vocational education at secondary education level following from junior high school, MTs, or other forms of equivalent or continuation of learning outcomes that are recognized as being equal to or equivalent to SMP or MTs". The meaning of vocational education as stipulated in the Law of the Republic of Indonesia Article 15 Number 20 of 2003 concerning the National Education System, which is secondary education which prepares students especially to work in certain fields. 
Vocational High School Program (SMK) is a secondary education program in the form of strengthening vocational education to prepare graduates who do not pursue higher education to be better prepared to enter the workforce under their competencies in their fields. Vocational education according to Evans (in Murniati, 2009: 1) was "part of the education system that prepares someone to be more able to work in a group of work or one line of work than other fields of work".

Vocational High School (SMK) as an educational institution, has a mission or goal to prepare employment that can fill workforce and a professional quality that is expected to play a role as a superior tool for business and industry in Indonesia to face global competition. To make SMK graduates could improve their quality competencies in implementing the learning process, SMKs and the Business / Industrial World (DU / DI) should establish cooperative relationships so that mastery of students' learning abilities could be obtained through learning activities at school and DU/DI.

The availability of DU/DI in collaboration with schools increasingly provides opportunities for graduates to be ready to enter the workforce. Therefore, schools often seek cooperation with various DU/DI in connecting graduates with the workforce. The public relations of schools in collaboration with stakeholders, especially DU/DI in labor absorption is expected to reduce unemployment. State Vocational School 4 Malang is one of the vocational schools in Malang which is subsequently used as an object in this study. The classroom learning activities were also carried out inside and outside the classroom. One of them was through industrial internship with several DU/DI. Therefore schools needed to establish good relations with partners, in this case, DU/DI. In addition to this partnership, students could apply the knowledge gained at school in their internships. Instead, the school got input on the latest information from DU/DI related to knowledge or technology that was currently developing and needed. Collaboration conducted by public relations SMK 4 Malang could have been as good as possible to attract DU/DI to be willing to work with the school, for that public relations SMK Negeri 4 Malang seek to play an important role in supporting cooperation by fostering good communication and harmonious relations to the public both internally and externally. The intended internal public were teachers, employees, and students, while the external public were the public, DU/DI and other organizations with an interest in education at SMK.

Forms of public relations activities implemented by SMK Negeri 4 Malang had been done by carrying out various promotions both manually and modernly, establishing partnership relations with DU/DI to provide the human resources needed, workshops by bringing in speakers from DU/DI, and conducting evaluations. Public Relations of SMK Negeri 4 Malang had to monitor several work programs that had been made with DU/DI to create the desired goals together. Public Relations of SMK Negeri 4 Malang played a role in creating a positive impression on the community and all institutions that work with schools. In addition to building a positive impression and maintaining public confidence in schools, public relations at SMK Negeri 4 Malang also developed an understanding about the aims and objectives of the school to public. Based on the background problem, the focus of this research was how the public relations support SMK Negeri 4 Malang towards partnership with DU/DI. 
This study aimed to determine the public relations support of vocational high schools, in this case, the study was conducted at State Vocational High School 4 Malang in partnership with DU/DI. Public Relations was a particular field or function by conducting two-way communication between the internal public (teachers, employees, and students) or external public (parents of students, communities and outside institutions) stated in their policies and practices to obtain mutual understanding, trust, and good faith. Every activity in an organization required management, as well as in public relations activities. Through public relations activities that support partnership efforts with DU/DI, it was expected that graduates of SMK Negeri 4 Malang would be more easily absorbed into a reliable workforce.

\section{METHOD}

This research was conducted by analyzing public relations activities in support of partnerships with the Business World / Industrial World (DU/DI) at SMK Negeri 4 Malang. So the most appropriate approach was to use a qualitative approach. This type of qualitative research seek to express symptoms thoroughly and contextually (holistic-contextual) through collecting data from a natural setting by utilizing the researcher as a key instrument. This research was descriptive and tent to use analysis with an inductive approach (PPKI UM, 2010: 28). According to Denzim and Lincoln (Moleong, 2016: 5) stated that qualitative research is research that use a natural setting, to interpret phenomena that occur and it is carried out by involving existing methods. In qualitative research everything that would be sought from the object of research and the exact problem were unclear, the data sources, the expected results are all unclear. The researcher is a key instrument in qualitative research (Sugiyono, 2011: 223). Therefore, the presence of researchers in this study acted as an instrument as well as collecting data. The data analysis stage in this study used the Miles and Huberman analysis model (2014: 20).

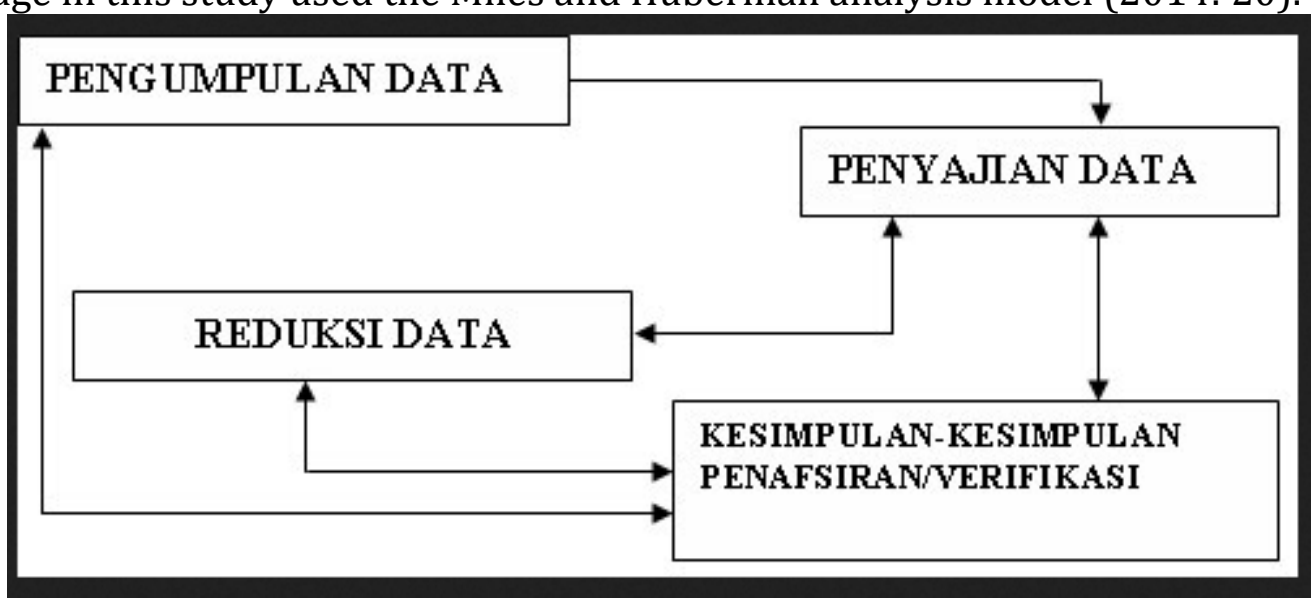

Source: Miles dan Huberman (2014:20)

Figure 1 Research Data Analysis Stage

\section{RESULT \& DISCUSSION}

According to Suhandang (2012: 73), the core task of public relations was the synchronization of information from the company with public reactions and 
responses to achieve a friendly atmosphere, mutual understanding, and a pleasant atmosphere in the company's interactions with the public. The public relations system in SMK Negeri 4 Malang was a public relations organization in SMK Negeri 4 Malang that aimed to connect the interests of schools with the community. PR includes BKK (Special Work Exchange) and its Internship. Thus the first was handling student relations with DU/DI in the placement of Internship, the second was for job recruitment. The formation of public relations in SMK 4 Malang was motivated by the view that in public services there must be a connection between the institution and the community, because people need to connect this, the SMK Negeri 4 Malang forms School Public Relations and the Vice Principal of PR which connected schools and schools the community. Besides, the organizational structure of existing governance, including public relations must exist in the organizational structure. Therefore the school included public relations, student affairs, curriculum, and infrastructure.

The goal to be achieved by establishing public relations of SMK Negeri 4 Malang was to improve public services. Public services were a good form of communication between institutions and the community. The product of the school was students because the school institution provided an educational service, the relationship between the school and the community could have been well established. This was to facilitate relations with internal and external parties, which was certainly for the existence and promotion of schools, all activities could be informed through public relations. The public relations organizing system which was done at SMK Negeri 4 Malang referred to predetermine planning, under semester program planning and annual programs. Some of these programs were complemented by implementing coordinators or committee formation. Organizing was done by the division of tasks and responsibilities that were different but still aiming at one goal; this action was carried out so that members in an organization could work well and had a sense of responsibility.

Human resources were the most important factor in the implementation of all public relations programs in SMK Negeri 4 Malang. To be able to carry out their duties properly, a PR had to have skills not only in the field of administrative tasks, but also had to have the ability to lead, organize, be able to provide motivation and encouragement to teachers, education staff, and students to create quality educational institutions. Public relations activities in supporting partnerships with the Business World/Industrial World (DU/DI) at SMK Negeri 4 Malang were, first, Public Relations looked for new industries to collaborate with SMK Negeri 4 Malang. Secondly, Public Relations and Industry met to make presentations to one another. Thirdly, PR made a MoU for cooperation with Industry. For industries that had long collaborated with State Vocational High School 4 Malang, PR regularly visited the Industry or at least communicated with each other via telephone or WhatsApp.

The form of partnership with the Business World/Industrial World (DU/DI) consisted of 9 forms of cooperation between SMK 4 Malang and Industry, such as a place for Internship, recruitment of workers, industry class, curriculum synchronization, place of internship teachers, UKK examiners from industry, visits Industry, CSR, and guest teachers as shown in the following picture: 


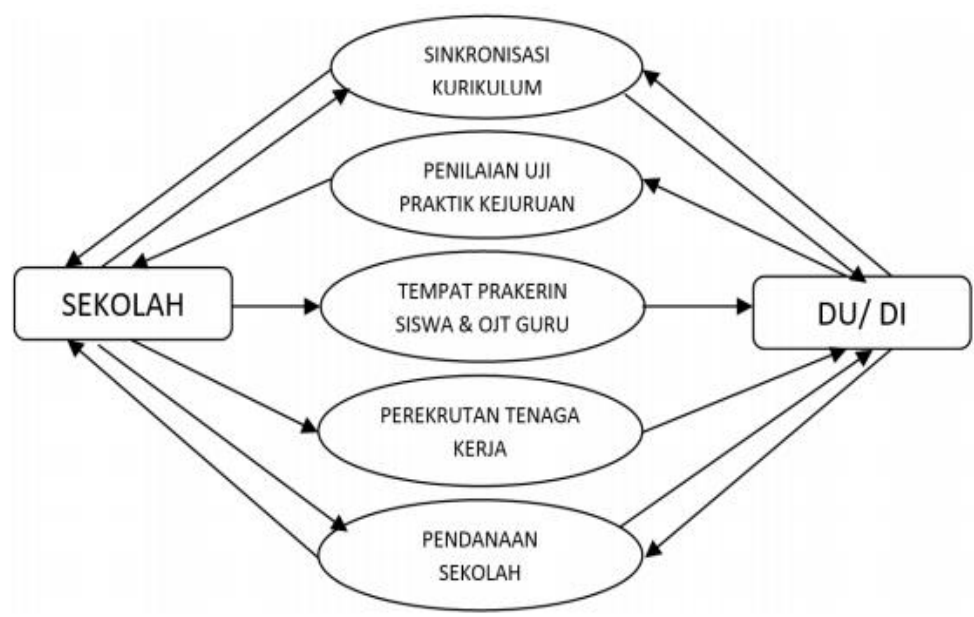

Figure 2. Form of Vocational Partnership with DU/DI

Based on Figure 2, it can be seen that the synchronization of curriculum, schools and workforce users (DU/DI) must synergize each other, especially in terms of learning material so that those who prepare the workforce, in this case, schools, establish mutually beneficial cooperation, give and take. Internship in the business world and the industrial world could provide the widest possible opportunities for students and teachers for work practices or internships so that education practitioners in schools could experience the work directly in DU/DI thus the teachers could prepare their students to be able to compete in the workforce as well as get accustomed to the work ethic at DU/DI. Recruitment of workers, it was time for labor users (DU/DI) to recruit workers from their sources (schools) to reduce brokering which harms prospective workers. Prefunding/recruitment funding, schools needed to budget funds for marketing the workforce (their students) because vocational school assignments were not enough to just graduate their students but also to market their graduates or search for graduates (tracery systems).

Public Relations of SMK Negeri 4 Malang in communicating with those who were asked for cooperation must be clear and detailed in order to create a good relationship and create cooperation, this would indirectly foster a positive and mutually beneficial relationship with the public, where schools could develop knowledge following the development of knowledge in the workforce and DU/DI would also gain labor benefits, get skilled prospective workers from or during the implementation of the cooperation if it was beneficial and had an impact on both parties.

In its implementation, public relations of SMK 4 Malang were done by 4 people, namely the Vice Principal of Public Relations, BKK, the field of industrial and administrative internship. Due to the large number of industries, the PR team automatically needed additional teams to be able to establish better cooperation. There were no more big obstacles between the public relations team, coordination and communication was going well, maybe there was only a difference in perception and it was common in the organization. Therefore the main obstacle for Public Relations of SMK Negeri 4 Malang was because of the lack of human resources if the added human resources might be more effective and efficient. The solution to overcome these obstacles was by sending students away according to 
DU/DI requests and schoolwork such as the semester exams done online. And the addition of human resources in the PR team, so that enough public relations work could be completed more effectively and efficiently.

The form of public relations activities that supported and firstly done in establishing cooperation with the new Industry, Public Relations of Vocational School 4 Malang would contact the Industry beforehand, and then visited the Industry for exploration. For partnership activities with existing industries, Public Relations would periodically visit the Industry at a minimum when monitoring or when delivering Internship students or alumni who would work. The form of public relations activities in supporting partnerships with the Business World/Industrial World (DU/DI) at SMK Negeri 4 Malang was for Industry which had long term cooperation with SMK Negeri 4 Malang, Public Relations conducted periodically industry visits. At least while delivering Internship students, the PR monitored and picked up students.

Before carrying out collaborative activities with DU/DI, several things needed to be organized. The first was to hold a MoU on some activities that would be approved since a lot of cooperation had been raised or submitted or requested for approval from the DU/DI that had been cooperating so far. Besides OJT, intern teachers, recruitment workers, there were also guest teachers, which meant that the DU/DI party was invited to teach in class. The lack of training organized by DU/DI partners could also have been a concern. The importance of training vocational students who were trained and educated by partners following the partners need in the field would certainly bring great benefits both for students, for schools and DU/DI itself. Due to the partnership between SMKs and DU/DI was not only just "there is" the cooperation between schools and the Industrial World, but also students could be optimally channeled following the workforce need. On the other hand, partners, in this case, the industrial world would also get benefit, that the workforce they recruit would work well and professionally following the needs of these partners. Collaboration in the form of training organized by partners or private forums to collaborate with vocational schools was very helpful in changing learning methods and maximizing partnerships between SMKs and the Industrial World.

Forms of school activities related to the Business World/Industrial World (DU/DI) were Curriculum Synchronization, Internship, internship teacher/OJT, cooperation as a guest teacher, as a place to visit industry, as recruitment of workers. The results of this study illustrated that the public relations of SMK Negeri 4 Malang had a working system following the programs that had been prepared in the short-term program. In its implementation, SMK Negeri 4 Malang formed a public relations team consisting of 4 personnel. This public relations team was the Vice Principal of Public Relations, BKK, the field of industry and administration internship. The main task of the public relations team was to convey information about school activities to the fullest, provide socialization to students about the internship program, socialization to school committees about student needs and provide information to DU/DI about the excellence of students of SMK Negeri 4 Malang.

From the research finding by Sri Utami (2010) it had been explained that in order to maximize the established partnerships; the partnership management 
(collaboration), the business world and the industrial world in Industrial Work Practices (Internship) could have been following the applicable procedures to equip students with competency expertise under the demands of national work standards. Schools (SMKs) had sought to increase partnerships (cooperation) between schools and the World of Business and Industry by involving all components related to the learning process both internal and outside the school related institutions and channeling also placing labor according to their fields. It was also confirmed by Okpor, Ikechukwu; Najimu, Hassan (2012) that Partnership was a clear facilitator and an approach in promoting sustainable development, especially in vocational education. This could be realized if the education field wants to establish relationships between the private sector and the public sector to partner effectively as well as that built-in technical vocational education in the country.

\section{CONCLUSION}

Vocational public relations activities were providing services to public about programs in Vocational Schools and becoming intermediaries inside and outside schools. These activities included: a) disseminating information about the program at the Vocational School to the community; b) looking for DU/DI to work with schools; c) making of the MoU; d) delivering and monitoring of Internship students; and e) channeling alumni to work at DU/DI. The form of vocational partnership with DU/DI consists of 9 forms of cooperation, namely a place for Internship, recruitment of workers, industry class, curriculum synchronization, internship teachers, UKK examiners from industry, industry visits, CSR, and guest teachers. The forms of public relations activities in supporting partnerships with DU/DI in SMK were a) conducting periodic industrial visits; b) renewing the form of cooperation with DU/DI; c) becoming an intermediary between vocational students undergoing Internship with DU/DI, this activity included exploratory, taking care of Internship permits, public relations monitoring activities, and facilitating communication between students, the community and DU/DI. Furthermore, Vocational Schools should carry out Control of the Implementation of the Partnership Program with the Business World and the Industrial World (DU/DI), through employing and enhancing vocational student training by partners or DU/DI in companies or industries around them following the competency expertise of each - students.

\section{REFERENCES}

Anggoro, M. Linggar. 2008. Teori Dan Profesi Kehumasan: Serta Aplikasinya Di Indonesia. Jakarta: Bumi Aksara.

Broom, Glen M., Scott M. Cutlip \& Allen H. Center. 2009. Effective Public Relations: Edisi Kesembilan. Jakarta: Kencana.

Coulson, Collin T. 2002. PR: Pedoman Praktis Untuk PR. Jakarta: PT. Bumi Aksara.

Divisi SDM. 2014. Pendidikan Kejuruan. (Online), (http://izzaucon.blogspot.co.id/2014/06/pendidikan-kejuruan.html), diakses pada 9 Maret 2018. 
Feruca, L. 2014. Dukungan Humas SMK Negeri 1 Magetan Terhadap Kemitraan Dengan Dunia Usaha/Dunia Industri (DU/DI). (Online), (http://jurnalmahasiswa.unesa.ac.id/index.php/ipap/article/view/9292), diakses 18 Februari 2018.

Okpor, Ikechukwu; Najimu, Hassan. 2012," Public-Private Partnership for Skill Acquisition and Vocational Technical Education Development in Nigeria" Mediterranean Journal of Social Sciences. Volume: 3 Halaman: 91-94.

Miles, Matthew dan Huberman Michael. 2014. Analisis Data Kualitatif. Jakarta: Universitas Indonesia Press.

Mulyono. 2008. Manajemen Administrasi \& Organisasi Pendidikan. Yogyakarta: ArRuzz Media.

Murniati AR dan Usman, Nasir. (2009). Implementasi Manajemen Stratejik: dalam Pemberdayaan Sekolah Menengah Kejuruan. Bandung: Citapustaka Media Perintis.

Moleong, Lexy J. 2016. Metodologi Penelitian Kualitatif. Bandung: PT. Remaja Rosdakarya.

Nova, F. 2011. Crisis Public Relations. Jakarta: Rajawali Press.

Pedoman Penulisan Karya Ilmiah. 2010. Malang: Universitas Negeri Malang.

Peraturan Pemerintah No. 66 Tahun 2010 tentang Perubahan Atas Peraturan Pemerintah No. 17 Tahun 2010 tentang Pengelolaan Dan Penyelenggaraan Pendidikan. Institut Teknologi Bandung. (Online), (http://www.fti.itb.ac.id/wp-content/uploads/2015/06/PP-no.-66-2010tentang-Perubahan-atas-PP-no.-17-tahun-2010.pdf), diakses 3 Maret 2018.

Pusat Pengembangan Tenaga Kependidikan. 2015. Peningkatan Kompetensi Kepala Sekolah Dalam Mengelola Implementasi Kurikulum: Kemitraan Sekolah Dengan Pihak Eksternal. Depok.

Rahmad, A. 2016. Manajemen Humas Sekolah. Yogyakarta: Media Akademi.

Sugiyono. 2011. Metode Penelitian Kuantitatif, Kualitatif Dan R\&D. Bandung: Alfabeta.

Suhandang, K. 2012. Studi Dan Penerapan Public Relations. Bandung: Nuansa Cendikia. 